\title{
Anorexigenic Effect of Cholecystokinin is Lost but That of CART (Cocaine and Amphetamine Regulated Transcript) Peptide Is Preserved in Monosodium Glutamate Obese Mice
}

\author{
B. ŽELEZNÁ ${ }^{1}$, J. MAIXNEROVÁ ${ }^{1}$, R. MATYŠKOVÁ ${ }^{1}$, R. HAUGVICOVÁ ${ }^{2}$, \\ D. BLOKEŠOVÁ ${ }^{1}$, L. MALETÍNSKÁ ${ }^{1}$
}

${ }^{1}$ Institute of Organic Chemistry and Biochemistry, Prague, ${ }^{2}$ Institute of Microbiology, Academy of Sciences of the Czech Republic, Prague, Czech Republic

Received January 23, 2008

Accepted September 8, 2008

On-line November 4, 2008

\section{Summary}

Monosodium glutamate (MSG) treatment of neonatal mice results in a selective damage to the arcuate nucleus (ARC) and development of obesity with increased adiposity at sustained body weight in the adulthood. Feeding pattern of the MSG obese mice is unusual. Our previous results showed that after 24-h fasting, MSG mice consumed negligible amount of food in several hours and therefore, it was impossible to register the effect of peptides attenuating food intake such as cholecystokinin (CCK) or cocaine- and amphetamine-regulated transcript (CART) peptide. To overcome this problem, two findings were used: firstly, orexigenic effect of neuropeptide $Y$ (NPY) was attenuated both by CCK or CART peptide in lean fed mice and secondly, orexigenic effect of NPY was preserved in fed rats with MSG obesity. In this study, short-term food intake in fed lean and MSG obese C57BL/6 male mice was measured after simultaneous central administration of orexigenic NPY with either CART peptide or peripherally administered CCK. Anorexigenic action of exogenous CART peptide was preserved in MSG obese mice. On the other hand, satiety effect of exogenous CCK was completely lost in MSG obese mice. In conclusion, effective leptin signaling in ARC is necessary for satiety effect of CCK.

\section{Key words}

Monosodium glutamate (MSG) obesity • Neuropeptide Y (NPY) • Cholecystokinin (CCK) - Cocaine and amphetamine regulated transcript (CART) peptide

\section{Corresponding author}

Dr. Lenka Maletínská, Institute of Organic Chemistry and
Biochemistry, Flemingovo nám. 2, 16610 Prague 6, Czech Republic. Fax +420 220183 571. E-mail: maletin@uochb.cas.cz

\section{Introduction}

The prevalence of obesity is increasing worldwide, which indicates that the primary cause of obesity lies in environmental and behavioral changes rather than in genetic modifications (for reviews see Coll et al. 2007, Cawthorne 2007). Among the environmental influences that disrupt body weight regulation, two factors play a major role: the passive overconsumption of energy-dense, high-fat diets and the decline in physical activity. It is important to emphasize that even a minor imbalance between energy intake and energy expenditure may lead to severe obesity. Obesity is accompanied with a high risk of type 2 diabetes, cholelithiasis, hypertension and coronary heart disease. The scale of the obesity problems and the increasing understanding of the complex systems regulating body weight have led to a renewed effort to identify possible explanation of the mechanisms regulating food intake and to improve the treatment of obesity, metabolic syndrome, and diabetes.

Information on the metabolic status of the organism enters and is processed in the hypothalamus and in the nucleus tractus solitarii (NTS) of the brainstem, which are interconnected reciprocally by hypothalamic neurons projecting to the brainstem (for reviews see Broberger 2005, Broberger and Hokfelt 2001, McMinn et al. 2000a). 
In the hypothalamic arcuate nucleus (ARC), adiposity signals leptin and insulin enhance expression and secretion of anorexigenic proopiomelanocortin (POMC) and of cocaine- and amphetamine-regulated transcript (CART) peptide by one type of neurons and attenuate production of orexigenic neuropeptide Y (NPY) and agouti-related protein (AgRP) by another neuron type (for reviews see Broberger and Hokfelt 2001, Elmquist $e t$ al. 1999, King 2005, Coll et al. 2007). POMC/CART and NPY/AgRP first order neurons with cell bodies in ARC project to the paraventricular nucleus of hypothalamus (PVN), where reduction in energy intake is mediated and to the lateral hypothalamic area (LHA), the "feeding" center of the brain (Broberger 2005, Broberger et al. 1999). From PVN and LHA, second order neurons project to the brainstem where gastrointestinal satiety signals such as cholecystokinin (CCK) are processed (McMinn et al. 2000a).

NPY is the most powerful regulator of food intake (Lambert et al. 1998). However, its orexigenic effect could be eliminated by anorexigenic peptides such as centrally administered CART peptide (Kristensen et al. 1998) or peripherally injected CCK (Rowland 1988, McMinn et al. 2000b).

Pathogenesis and therapy of obesity are studied using appropriate animal models. Models of monogenic (such as $o b / o b$ or $d b / d b$ mice, deficient in leptin or its receptor), chemically induced (such as monosodium glutamate (MSG)-induced obesity) or diet-induced obesity (DIO) were established (for reviews see Butler and Cone 2001, Buettner et al. 2007, Casper et al. 2008).

MSG obesity results from the treatment of rodents in their first days of life. Specific lesions occur in ARC (Olney 1969) leaving most cells of ARC damaged and those of other hypothalamic nuclei untouched (Elefteriou et al. 2003, Maletínská et al. 2006). Subsequent changes show the importance of ARC in the regulation of metabolism. In the MSG-treated animals, ARC area is shrunk, third ventricle widened, and median eminence thinned (Broberger et al. 1998). MSG treatment lowers production of growth-hormone releasing hormone (Tamura et al. 2002) that results in shortened body length, and atrophy of pituitaries, gonads, and optical nerves. In ARC of MSG-treated rodents, leptin and insulin signaling is impaired (Maletínská et al. 2006, Dawson et al. 1997) and production of anorexigenic CART peptide and orexigenic NPY is inhibited (Broberger et al. 1998, Broberger 1999). Both NPY and CART are produced also in other hypothalamic areas such as PVN and LHA. NPY immunoreactivity was preserved in the PVN of MSG mice (Broberger et al. 1998), probably by local NPY expression (Kerkerian and Pelletier 1986). Besides, CART is expressed in half of cell bodies of nodose ganglion in the vagus nerve which also express CART (Broberger and Hokfelt 2001, Broberger 2005). The extra-ARC sources of NPY and CART are preserved after the MSG treatment.

MSG-treated rodents do not differentiate feeding at light and dark because of their deteriorated retina cells (Edelstein et al. 1995, Mistlberger et al. 1999), and develop obesity with increased adiposity at sustained body weight (Djazayery et al. 1979), which results rather from a lower metabolic rate than from elevated food intake (Morris et al. 1998). The possible reason could be a reduced effect of anorexigenic peptides that are produced or processed in ARC. After 24-h fasting, the MSG obese NMRI mice showed substantially attenuated food intake compared with their lean controls which made impossible to follow their response either to peripherally administered satiety hormone cholecystokinin octapeptide (CCK-8) (Maletínská et al. 2006) or to centrally injected anorexigenic CART peptide (our preliminary experiments).

Two previous findings inspired us how to overcome this problem: a) in lean fed mice, both CCK and CART peptide inhibited orexigenic effect of NPY (Rowland 1988, Lambert et al. 1998, Kristensen et al. 1998), and b) the MSG-treated rats had preserved orexigenic effect of NPY (Tang-Christensen et al. 1998). In this study, food intake in freely fed MSG obese C57BL/6 mice after parallel administration of orexigenic NPY with either CART peptide or CCK was followed. The aim was to find out whether anorexigenic CART peptide and satiety peptide CCK take part in food intake regulation of mice with MSG obesity and whether functioning ARC is necessary for anorexigenic effect of CCK or CART peptide generally.

\section{Methods}

\section{Experimental animals}

Male C57BL/6 mice (Institute of Molecular Genetics, Prague, Czech Republic) were housed at a temperature of $23{ }^{\circ} \mathrm{C}$ and a daily cycle of $12 \mathrm{~h}$ light and dark (light from 6:00). They were given ad libitum water and standard chow diet that contained 25, 9 and $66 \%$ calories as protein, fat and carbohydrate, with energy of 3.4 kcal/g (ST-1, Velaz, Koleč, Czech Republic). Daily food intake (24-h food intake) was determined regularly 
every week from 6 to 16 weeks of age. All experiments followed the ethical guidelines for animal experiments and the law of the Czech Republic No. 246/1992.

For MSG obesity, newborn mice were subcutaneously (SC) administered with L-glutamic acid sodium salt hydrate (Sigma, St. Louis, USA) $(4 \mathrm{mg} / \mathrm{g}$ body weight) daily from postnatal day 2 to 8 .

MSG-treated mice aged 16 weeks and their agerelated controls were used in feeding experiments. After completing food intake experiments, mice were sacrificed next morning between 8:00 and 9:00 a.m. $(n=20-25)$. Serum leptin, and glucose levels were determined. White adipose tissue (subcutaneous, abdominal, gonadal) of all mice were dissected and weighed.

\section{Brain histology}

Three controls and three MSG-treated mice (16 week-old) were perfused with $0.1 \mathrm{M}$ phosphate buffer ( $\mathrm{pH}$ 7.4) containing $4 \%$ paraformaldehyde, $0.1 \%$ glutar-aldehyde and $10 \%$ picric acid $(\mathrm{w} / \mathrm{w})$. Coronal sections from the whole hypothalamus were collected and lesions in the arcuate nucleus were inspected (Maletínská et al. 2006).

\section{Blood serum components}

Leptin concentrations in sera were quantified by ELISA assay (BioVendor, Brno, Czech Republic). Serum glucose levels were measured by a glucometer (Glucocard, Arkray, Kyoto, Japan).

\section{Food intake experiments}

At the age of 16 weeks, lean or MSG-treated mice were implanted with cannulas (Plastics One, Roanoke, USA) into their third ventricle (AP $2 \mathrm{~mm}$, V $3 \mathrm{~mm}$ ) as described earlier (Maletínská et al. 2007). Animals were placed into separate cages and allowed at least seven days to recover from surgery with free access to food and water before being used in the experiment.

\section{Peptides}

Porcine NPY and cholecystokinin octapeptide (CCK-8, Asp-Tyr( $\left.\mathrm{SO}_{3} \mathrm{H}\right)$-Met-Gly-Trp-Met-Asp-Phe$\mathrm{NH}_{2}$ ) were obtained from NeoMPS (Strasbourg, France). CART(61-102) was purchased from Bachem (Bubendorf, Switzerland).

\section{Feeding test}

Between 8:00 and 9:00 a.m., each individual group of 6-8 mice underwent one of the following treatments: 1) intracerebroventricular (ICV) injection of saline using an infusion pump, 2) ICV injection of NPY at a dose of $5 \mu \mathrm{g}$ per mouse, 3) ICV injection of CART(61-102) peptide at doses of either 0.1 or $0.5 \mu \mathrm{g}$ per mouse, 4) ICV co-injection of NPY at a dose of $5 \mu \mathrm{g}$ plus CART(61-102) peptide at doses of either 0.1 or $0.5 \mu \mathrm{g}$ per mouse, 5) intraperitoneal (IP) injection of CCK-8 at a dose of of either 4 or $40 \mu \mathrm{g} / \mathrm{kg}, 6) \mathrm{ICV}$ injection of NPY at a dose of $5 \mu \mathrm{g}$ per mouse followed 45 min later by IP injection of CCK- 8 at a dose of of either 4 or $40 \mu \mathrm{g} / \mathrm{kg}$. All peptides were dissolved in saline. Volume of IP injected solutions was $0.2 \mathrm{ml} /$ mouse; that of ICV injected solutions was $5 \mu \mathrm{l}$ per mouse. All ICV administered solutions were infused in $20 \mathrm{~s}$ and the infusion cannula was left in place for further $20 \mathrm{~s}$ to prevent reflux. Each animal was used only once; the experiment was repeated with a new set of mice.

Fifteen min after the ICV injection, mice were given weighed food pellets. Food intake was registered every $30 \mathrm{~min}$ and followed for $6 \mathrm{~h}$. Animals had free access to water during the experiment. The results were expressed in grams of food consumed. The placement of cannula was verified histologically after the experiment.

\section{Statistics}

Data are presented as means \pm SEM for the number of animals indicated in Figures and Table. They were analyzed by one-way ANOVA followed by Tukey post hoc test using Graph-Pad Software (San Diego, CA, USA). $\mathrm{p}<0.05$ was considered statistically significant.

\section{Results}

C57BL/6 mice treated in their neonatal period with MSG developed severe obesity at the age of 16 weeks, although their average daily food intake was lower than that of lean untreated controls $(3.62 \pm 0.23 \mathrm{~g}$ vs. $4.07 \pm 0.16 \mathrm{~g}$ ). The ratio of fat weight (subcutaneous, abdominal, plus epididymal) to body weight was about eight times enhanced and leptin level was very substantially increased in MSG-treated mice compared with lean controls. On the other hand, glucose level of the MSG-treated mice did not differ from that of lean controls (Table 1). Analysis of serial coronal sections of the hypothalamus showed an obvious disappearance of neurons in ARC of MSG-treated mice (Fig. 1) while adjacent hypothalamic nuclei did not show any sign of damage similarly as in our previous study with NMRI mice (Maletínská et al. 2006). 
Table 1. Metabolic parameters of freely fed 16-week-old lean and MSG male C57BL/6 mice.

\begin{tabular}{llll}
\hline Characterization & Ratio of fat/body weight & Glucose (mmol/l) & Leptin (ng/ml) \\
\hline Control & $1.41 \pm 0.41$ & $8.20 \pm 0.64$ & $7.00 \pm 1.21$ \\
$M S G$ & $13.48 \pm 0.99 * * *$ & $7.88 \pm 0.62$ & $45.55 \pm 6.54 * * *$ \\
\hline
\end{tabular}

All values are expressed as the mean \pm SEM $(n=20-25)$. Significant difference: $* * * p<0.001$ vs. controls.

\section{CONTROL}

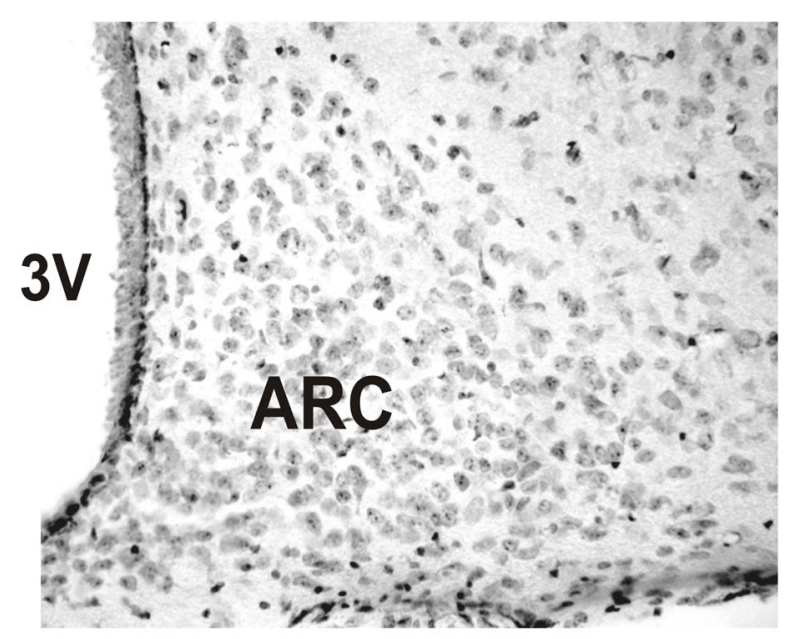

\section{MSG}

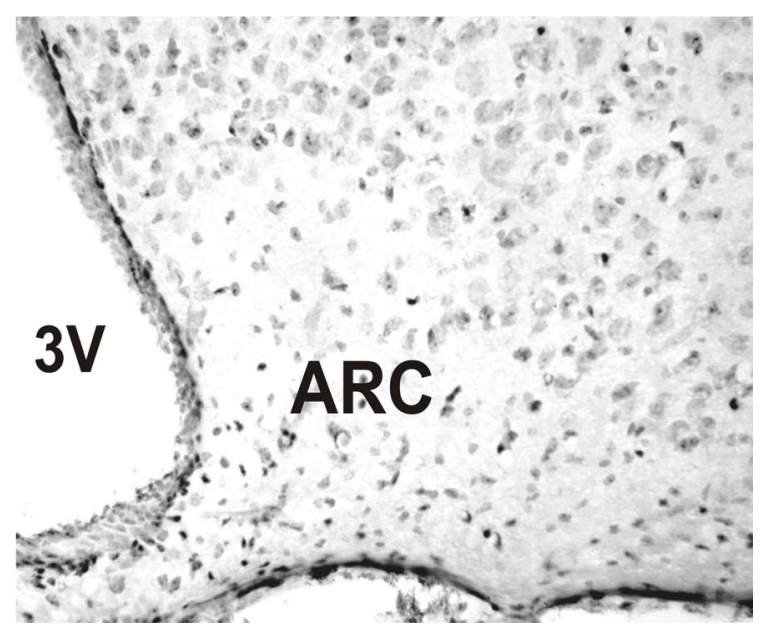

Fig. 1. MSG lesions in hypothalamic arcuate nucleus (ARC). Coronal sections of the hypothalamus of MSG-treated mice stained with $0.1 \%$ cresyl violet acetate show disappearance of neurons in ARC compared with control mice ( $3 \mathrm{~V}$ - third ventricle) ( $n=3$ per group).

To determine whether NPY pretreatment attenuates the feeding response to $\mathrm{CCK}$, mice received $5 \mu \mathrm{g}$ ICV of NPY, followed 45 min later (at a time of the first food intake measurement) by IP injection of CCK, similarly as in the study of McMinn et al. (2000b). In

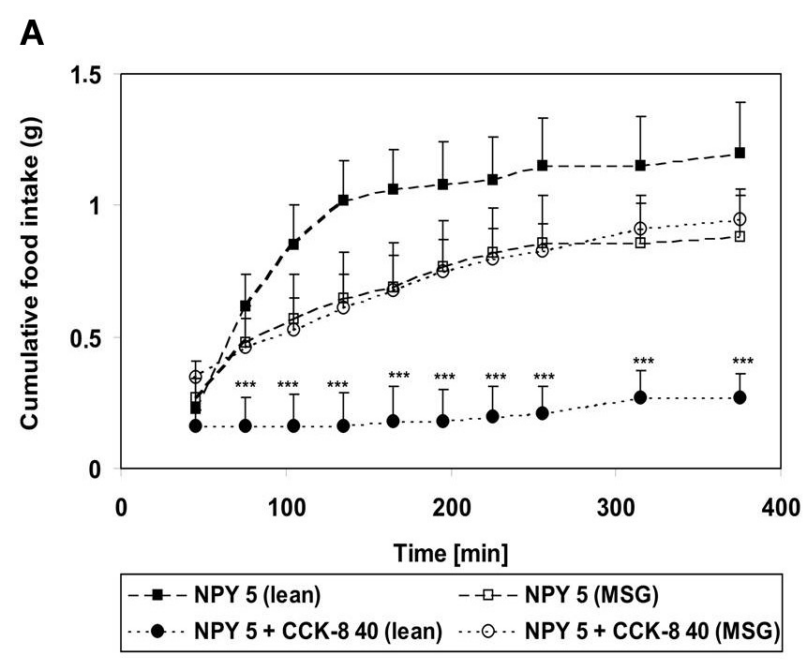

B

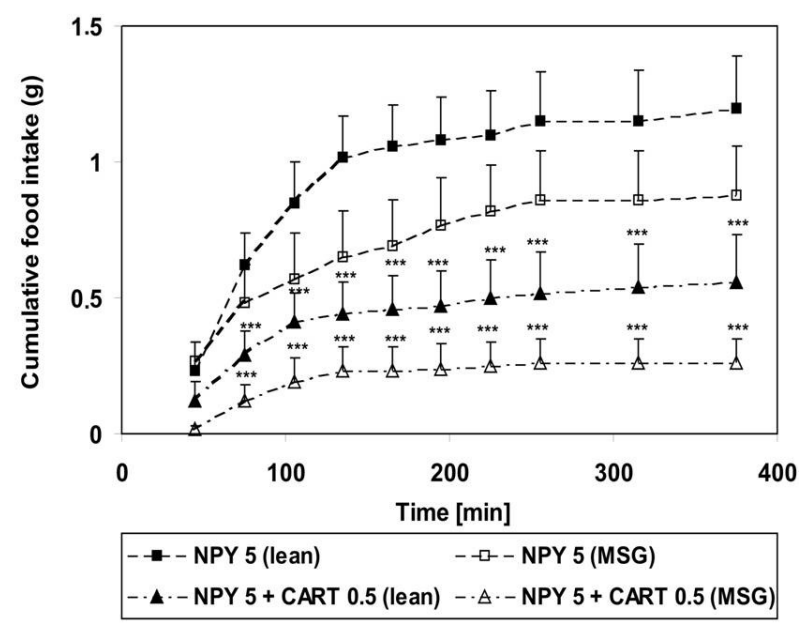

Fig. 2. A. Cumulative food intake response of freely fed lean and MSG mice to NPY at a dose of $5 \mu \mathrm{g} /$ mouse and NPY at a dose of $5 \mu \mathrm{g} /$ mouse plus CCK-8 (dose $40 \mu \mathrm{g} / \mathrm{kg}$ ). B. Cumulative food intake response of freely fed lean and MSG mice to NPY at a dose of $5 \mu \mathrm{g} /$ mouse and NPY ( $5 \mu \mathrm{g} /$ mouse) plus CART(61-102) at a dose of $0.5 \mu \mathrm{g} / \mathrm{kg}$. Food intake is expressed in grams of food consumed ( $n=6-8$ mice per group). $* * * p<0.001$ vs. respective group treated by NPY at a dose of $5 \mu \mathrm{g} /$ mouse.

lean controls, orexigenic action of NPY was completely abolished by CCK-8, which acted in a dose-dependent way (Figs 2a and 3); similarly, it was lowered by coadministration of CART peptide also in a dose-dependent way (Figs 2 b and 3). In MSG obese mice, CCK-8 did not 


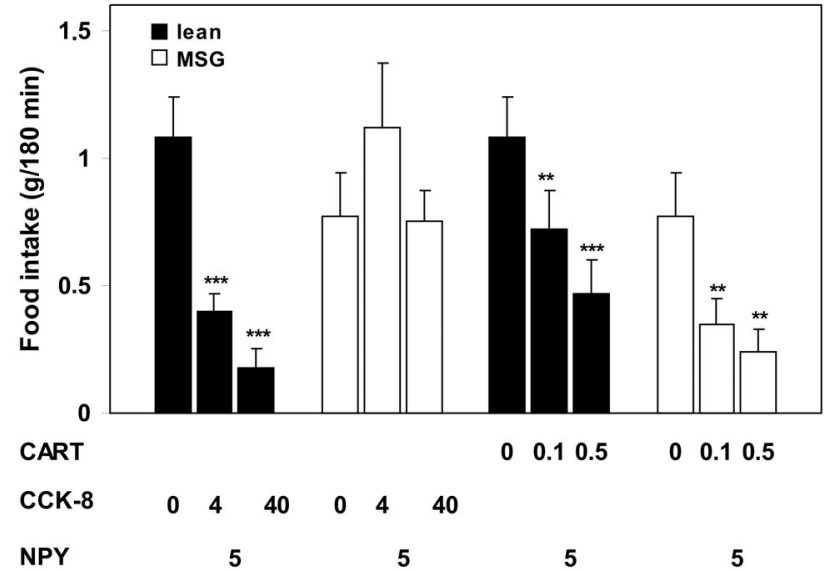

Fig. 3. Inhibition of NPY-induced food intake (dose $5 \mu \mathrm{g} /$ mouse) by CART(61-102) (0.1 and $0.5 \mu \mathrm{g} /$ mouse) or CCK-8 (4 and $40 \mu \mathrm{g} / \mathrm{kg}), 195 \mathrm{~min}$ after administration of NPY in lean and MSG mice. Food intake is expressed in grams of food consumed per 180 min ( $n=6-8$ mice per group). * $\mathrm{p}<0.05$, ** $\mathrm{p}<0.01$, $* * * p<0.001$ vs. respective group treated by NPY at a dose of $5 \mu \mathrm{g} /$ mouse.

affect orexigenic effect of NPY at all; CART peptide attenuated the NPY induced feeding to a lower extent than in lean controls (Figs 2a, 2b and 3).

\section{Discussion}

NPY exerts its effects on food intake at the level of the PVN and LHA which receive a dense projection from the arcuate nucleus and where NPY Y1 receptors are expressed (Broberger and Hokfelt 2001). MSG treatment of neonatal rodents cut virtually all projections from ARC, but disabled neither the orexigenic effect of exogenous NPY nor the anorexigenic effect of exogenous CART peptide in the MSG obese C57BL/6 mice (Figs 2a and 2b). In this study, exogenous CART peptide attenuated orexigenic effect of NPY most probably through specific binding sites for CART peptide (Maletínská et al. 2007) that are located outside ARC. Until now, molecular character of CART peptide receptors has not been elucidated. It is possible that in MSG obese mice, exogenous NPY and CART peptide can act through PVN or LHA via their intact neurons and preserved neuronal circuits.

Anorexigenic effect of CCK is mediated by CCK-A receptors that are located both in central nervous system and periphery. CCK produces satiety in two different brain areas: in nucleus tractus solitarius (NTS) of the brainstem and in medial-basal hypothalamus (Luckman and Lawrence 2003, Cummings and Overduin 2007). Although none of these areas was damaged by the MSG treatment, CCK-8 did not affect NPY-induced feeding in MSG obese mice in this study which was in accordance with our previous results using NMRI mice (Maletínská et al. 2006). It was shown previously that MSG obese rodents responded neither to systemic nor to central leptin administration (Dawson et al.1997, TangChristensen et al. 1999) similarly as did Koletsky obese $f a^{k} / f a^{k}$ rats (Takaya et al. 1996, Morton et al. 2003) or obese $d b / d b$ mice (Morton et al. 2003), from a common reason - lack of functional leptin receptors, which was restricted to $\mathrm{ARC}$ in the MSG obese rodents or was total in Koletsky rats or $d b / d b$ mice. Interestingly, both MSG obese mice and rodents with impaired leptin receptor did not provide satiety response to CCK (Morton et al. 2005, Maletínská et al. 2006). After leptin signaling had been restored in ARC of Koletsky rats using ARC directed injection of human lepr ${ }^{\mathrm{b}}$ adenovirus, effect of CCK on the activation of neurons of NTS and area postrema, where satiety-related inputs are processed, was reconstituted (Morton et al. 2005). It shows that ARC-based leptin receptors are necessary for $\mathrm{CCK}$-induced satiety and explains irresponsiveness to CCK-8 in MSG obese mice.

In MSG obese mice, CART peptide production in their damaged ARC is disabled, but anorexigenic action of exogenous CART peptide is preserved. On the other hand, CCK production is untouched in MSG obese mice, but CCK satiety effect is lost; possibly due to a non-functional leptin signaling in the ARC, which is crucial for mediating satiety response to CCK.

\section{Conflict of Interest}

There is no conflict of interest.

\section{Acknowledgements}

The study was supported by grants 303/05/0614 and 305/06/0427 (GA CR) and Z4 0550506 (Academy of Sciences CR). We are indebted to A. Vytejčková and H. Vysušilová for excellent technical assistance, and to Dr. Z. Pirník and Dr. A. Kiss (Institute of Experimental Endocrinology, Bratislava) for brain histology. 


\section{References}

BROBERGER C: Hypothalamic cocaine- and amphetamine-regulated transcript (CART) neurons: histochemical relationship to thyrotropin-releasing hormone, melanin-concentrating hormone, orexin/hypocretin and neuropeptide Y. Brain Res 848: 101-113, 1999.

BROBERGER C: Brain regulation of food intake and appetite: molecules and networks. J Intern Med 258: 301-327, 2005.

BROBERGER C, JOHANSEN J, JOHANSSON C, SCHALLING M, HOKFELT T: The neuropeptide Y/agouti generelated protein (AGRP) brain circuitry in normal, anorectic, and monosodium glutamate-treated mice. Proc Natl Acad Sci USA 95: 15043-15048, 1998.

BROBERGER C, VISSER TJ, KUHAR MJ, HOKFELT T: Neuropeptide Y innervation and neuropeptide-Y-Y1receptor-expressing neurons in the paraventricular hypothalamic nucleus of the mouse. Neuroendocrinology 70: 295-305, 1999.

BROBERGER C, HOKFELT T: Hypothalamic and vagal neuropeptide circuitries regulating food intake. Physiol Behav 74: 669-682, 2001.

BUETTNER R, SCHOLMERICH J, BOLLHEIMER LC: High-fat diets: modeling the metabolic disorders of human obesity in rodents. Obesity 15: 798-808, 2007.

BUTLER AA, CONE RD: Knockout models resulting in the development of obesity. Trends Genet 17: S50-S54, 2001.

CASPER R, SULLIVAN EL, TECOTT L: Relevance of animal models to human eating disorders and obesity. Psychopharmacology 199: 313-329, 2008.

CAWTHORNE MA: Opportunities and challenges for the development of pharmacological therapies for obesity treatment. Obes Rev 8 (Suppl 1): 131-136, 2007.

COLL AP, FAROOQI S, O'RAHILLY SO: The hormonal control of food intake. Cell 129: 251-262, 2007.

CUMMINGS DE, OVERDUIN J: Gastrointestinal regulation of food intake. J Clin Invest 117: 13-23, 2007.

DAWSON R, PELLEYMOUNTER MA, MIILLARD WJ, LIU S, EPPLER B: Attenuation of leptin-mediated effects by monosodium glutamate-induced arcuate nucleus damage. Am J Physiol 273: E202-E206, 1997.

DJAZAYERY A, MILLER DS, STOCK MJ: Energy balances in obese mice. Nutr Metab 23: 357-367, 1979.

EDELSTEIN K, PFAUS JG, RUSAK B, AMIR S: Neonatal monosodium glutamate treatment prevents effects of constant light on circadian temperature rhythms of adult rats. Brain Res 675: 135-142, 1995.

ELEFTERIOU F, TAKEDA S, LIU X, ARMSTRONG D, KARSENTY G: Monosodium glutamate-sensitive hypothalamic neurons contribute to the control of bone mass. Endocrinology 144: 3842-3847, 2003.

ELMQUIST JK, ELIAS CF, SAPER CB: From lesions to leptin: hypothalamic control of food intake and body weight. Neuron 22: 221-232, 1999.

KERKÉRIAN L, PELLETIER G: Effects of monosodium L-glutamate administration on neuropeptide Y-containing neurons in the rat hypothalamus. Brain Res 369: 388-390, 1986.

KING PJ: The hypothalamus and obesity. Curr Drug Targets 6: 225-240, 2005.

KRISTENSEN P, JUDGE ME, THIM L, RIBEL U, CHRISTIANSEN KN, WULFF BS, CLAUSEN JT, JENSEN PB, MADSEN OD, VRANG N, LARSEN PJ, HASTRUP S: Hypothalamic CART is a new anorectic peptide regulated by leptin. Nature 393: 72-76, 1998.

LAMBERT PD, COUCEYRO PR, MC GIRR KM, DALL VECHIA SE, SMITH Y, KUHAR MJ: CART peptides in the central control of feeding and interactions with neuropeptide Y. Synapse 29: 293-298, 1998.

LUCKMAN SM, LAWRENCE CB: Anorectic brainstem peptides: more pieces to the puzzle. Trends Endocrinol Metab 14: 60-65, 2003.

MALETÍNSKÁ L, SHAMAS TOMA R, PIRNIK Z, KISS A, SLANINOVÁ J, HALUZÍK M, ŽELEZNÁ B: Effect of cholecystokinin on feeding is attenuated in monosodium glutamate obese mice. Reg Peptides 136: 58-63, 2006.

MALETÍNSKÁ L, MAIXNEROVÁ J, MATYŠKOVÁ R, HAUGVICOVÁ R, ŠLONCOVÁ E, ELBERT T, SLANINOVÁ J, ŽELEZNÁ B: Cocaine- and amphetamine-regulated transcript (CART) peptide specific binding in pheochromocytoma cells PC12. Eur J Pharmacol 559: 109-104, 2007.

MCMINN JE, BASKIN DG, SCHWARTZ MW: Neuroendocrine mechanisms regulating food intake and body weight. Obesity Rev. 1: 37-46, 2000a. 
MCMINN JE, SINDELAR DK, HAVEL PJ, SCHWARTZ MW: Leptin deficiency induced by fasting impairs the satiety response to cholecystokinin. Endocrinology 141: 4442-4448, $2000 \mathrm{~b}$.

MISTLBERGER RE, ANTHE MC: Neonatal monosodium glutamate alters circadian organization of feeding, food anticipatory activity and photic masking in the rat. Brain Res 842: 73-83, 1999.

MORRIS MJ, TORTELLI CF, FILIPPIS A, PROIETTO J: Reduced BAT function as a mechanism for obesity in the hypophagic, neuropeptide Y deficient monosodium glutamate-treated rat. Reg Peptides 75-76: 441-447, 1998.

MORTON GJ, NISWENDER KD, RHODES CJ, MYERS Jr MG, BLEVINS JE, BASKIN DG, SCHWARTZ MW: Arcuate nucleus-specific leptin receptor gene therapy attenuates the obesity phenotype of Koletsky $\left(\mathrm{fa}^{\mathrm{k}} / \mathrm{fa}^{\mathrm{k}}\right)$ rats. Endocrinology 144: 2016-2024, 2003.

MORTON GJ, BLEVINS JE, WILLIAMS DL, NISWENDER KD, GELLING RW, RHODES CJ, BASKIN DG, SCHWARTZ MW: Leptin action in the forebrain regulates the hindbrain response to satiety signals. $J$ Clin Invest 115: 703-710, 2005.

OLNEY JW: Brain lesions, obesity, and other disturbances in mice treated with monosodium glutamate. Science 164: 719-721, 1969.

ROWLAND NE: Peripheral and central satiety factors in neuropeptide Y-induced feeding in rats. Peptides 9: 989-992, 1988.

TAKAYA K, OGAWA Y, HIRAOKA J, HOSODA K, YAMORI Y, NAKAO K, KOLETSKY RJ: Nonsense mutation of leptin receptor in the obese spontaneously hypertensive Koletsky rat. Nat Genet 14: 130-131, 1996.

TAMURA H, KAMEGAI J, SHIMIZU T, ISHII S, SUGIHARA H, OIKAWA S: Ghrelin stimulates GH but not food intake in arcuate nucleus ablated rats. Endocrinology 143: 3268-3275, 2002.

TANG-CHRISTENSEN M, VRANG N, LARSEN PJ: Glucagon-like peptide 1(7-36) amide's central inhibition of feeding and peripheral inhibition of drinking are abolished by neonatal monosodium glutamate treatment. Diabetes 47: 530-537, 1998.

TANG-CHRISTENSEN M, HOLST JJ, HARTMANN B, VRANG N: The arcuate nucleus is pivotal in mediating the anorectic effects of centrally administered leptin. Neuroreport 10: 1183-1187, 1999. 